\title{
Market segment of families with children: a new stimulus for modern Czech spa industry?
}

\section{Darina Jelínková}

Tomas Bata University in Zlin,

Zlin, Czech Republic,

Email:djelinkova@fame.utb.cr.

\section{Zuzana Tučková}

Tomas Bata University in Zlin,

Zlin, Crech Republic,

Email:tuckova@fame.utb.cr.

\section{Zuzana Jurigová}

Tomas Bata University in Zlin,

Zlin, Crech Republic,

Email: zjurigova@fame.utb.cz.

Abstract. The paper deals with a comprehensive range of hotel services for families with children at spa facilities of the Czech Republic, in line with current trends and requirements of this market segment. The main goal of this paper is to determine the preferences, needs and requirements of families with children in terms of amenities and services offer at spa hotels designated specifically for this target group. The secondary goal is to determine the current state of hotel services and facilities of Czech First Class hotels, which are the holders of the Baby Friendly Certificate. Subsequently, service offerings of these spa hotels are

Received: January, 2017 1st Revision: March, 2017 Accepted: May, 2017

DOI: $10.14254 / 2071-$ $8330.2017 / 10-2 / 12$ compared with the existing range of services for families with children in the selected Czech spas. In conclusion, based on the information obtained from the analyses and marketing research, a solution of the services portfolio intended for the market segment of families with children is recommended here using marketing mix as applied to tourism.

Keywords: spa, market segment of families with children; hospitality management; marketing research.

JEL Classification: Z33

\section{INTRODUCTION}

Nowadays, tourism is influenced by many modern forms that are aimed at attracting the appropriate target groups in order to fulfill the customer's needs. One of the oldest type of tourism, that is now evolving 
and developing, is spa tourism due to the growing dynamics of leisure industry (Erdeli, 2011). At the same time aging of Western European population means an extraordinary growth potential for spa, especially in Romania, which decides to do business in spa market. It is due to the fact that in 2030, the number of people over 60 will represent more than a quarter of the population of France, $37-38 \%$ in Germany and $30-31 \%$ in the Nordic countries. This development is based on the average life expectancy, for example in France 75 years for men and 83 years for women (Moraru, 2015). This is also confirmed by Chen et al. (2013) who claim that the reason in aging society resided in better medical services, birth rates and higher average life expectancy. Another target group of spa tourism are families with children as it serves as an amusement, medical care and fun altogether. Hall (2013) points out that positive perspective of the future of Czech and Slovak spas are seen in the increasing number of families with children. Moreover, spa treatments and spa travelers see as one of the benefits of this type of tourism to enrich and develop better relationships not only with partners but also children (Tabacchi, 2010). For this reason, the paper deals with a research aimed at the current situation of spa services in the chosen Czech region aimed at target group family with children. As no such research in the Czech Republic has been conducted yet, the exclusivity of this primary research will lead to other steps that can improve the level of spa services for family with children in the Czech Republic. Moreover, it can serve for development of marketing planning of individual spa facilities based on the need and preferences of families with children.

\section{LITERATURE REVIEW}

Nowadays tourism represents comparatively stable and rapidly growing area of the economy all over the world. Nevertheless, its growth depends on a particular tourist region. There is an increasing demand for tourism services, mainly in developing areas. Considering that competition between countries, cities and tourism enterprises is still growing and is becoming only stronger (Herget, Petrů \& Abrhám, 2015), it is important to focus primarily on consumer needs. On the tourist market, the importance of well-chosen marketing tools is even higher if the target client is family with children, as participation of children in tourism decision-making process may be crucial because parents are satisfied only if their child is happy (Niemczyk, 2015).

\subsection{Spa tourism}

Spa concept is defined differently by many authors. Some authors suppose the idea that SPA definition arises from the Latin acronym SPA (Sanus Per Aqua that is Health through water). According to other sources, SPA is a name of a city in Belgium which was during the Roman times used for its spas, therefore, has become very popular. Another definition by the International SPA Association (2004) states that the SPA is focused on improving the overall well-being through a variety of professional services that primarily support the renewal of mind, body and spirit. According to Mueller and Kaufmann (2006) the spa industry is characterized by a harmony of body, mind and spirit, in other words as beauty care. This term in itself also reflects a healthy diet, relaxation, meditation, mental activity and many others. Definition of spas are given by professional spa associations all over the world. Spa Business Association (SpaBA) uses the following three definitions with regard to the chronological development of the spa industry:

- Historical: Spas were special places, where natural spring waters were reputed to cure from a range of health problems;

- Traditional: Spas with tradition, places for treatment and rehabilitation, these spas are established for the purpose of hydrotherapy carried out under medical supervision; 
- Contemporary: Currently the spa facilities are primarily used for physical and emotional well-being (Georgiev \& Vasileva, 2010).

The importance of the spa industry is currently perceived at several levels. According to Stanciulescu, Diasconescu \& Diaconescu (2015) spa tourism itself is widely recognized as a fundamental element of the movement for health and wellness, utilizing a wide range of curative and preventive activities. Nejdl (2005) states that spa is primarily a socio-economic and medical category. Economic expresses that it is a part of the general category of economy at both levels - macroeconomic and microeconomic. A number of authors deal with the economic benefits of medical tourism. One of them is Molnár (2010) who distinguishes the benefits of spas on direct, indirect and generated, while as recipients of these benefits are considered economic enterprises as well as municipalities or state. The main problem is not theoretical definition of these benefits, but their monitoring and quantification. For some effects it is relatively simple and statistically well captured (job creation), in other cases it is much more difficult. However, the most complex are measurements of indirect and induced economic benefits of spas. Still, this problem is for a long time not solved in the Czech Republic (Attl, 2011).

\subsection{Spa tourism in the Czech Republic}

Czech spa industry is an integral part of the health system in the Czech Republic. For some regions, the spa industry is a crucial economic field whose existence determines the direction and level of their economic development (Attl, 2011; Cohen \& Bodeker, 2008). The spa industry is not directly dependent on macroeconomic developments of the Czech Republic (GDP), nor on the rate of growth of tourism (Tourism Contribution to GDP). Spa tourism, apart from the economic situation, is also susceptible to other factors, such as climatic conditions (e.g. floods etc.), spa care financing system (conditions for complex and contributory spa care), new trends in medical care (shortening of stays, development of wellness services etc.) (Attl \& Studnička, 2012).

In the Czech Republic, the spa industry is largely privatized. From 104 of spa institutes (ÚZIS, (C) 2011) there are only 10 spas which are in the possession of one of the central state bodies (Ministry of Health, Ministry of Defence). Therefore, it is evident that the vast gravity associated with the development and investment in the spa industry is dependent on private entities. But there are exceptions which include mainly the possibility of financing of spas from the Regional Operational Programmes (Attl \& Studnička, 2012).

From the perspective of the Czech Republic, the spa industry is small but economically successful field. Another view but arises when we look at the spa industry from a regional perspective (Attl \& Studnička, 2012). Generally, there are three primary benefits of spas - economic (GDP, employment), medical (irreplaceable role in the follow-up treatment, today also in the preventive health care) and social (Nejdl, 2005; Vystoupil, Šauer \& Studnička, 2011). In addition, the spa industry is also an important indicator of the condition of the environment with mostly positive influence on the sustainable development of the region (Attl \& Studnička, 2012). This arises mainly from its legislative amendment in Act no. 164/2001 Coll., regarding natural medicinal resources, sources of natural mineral water, natural spas and health-resorts and related law amendments (Spa Act) and respective implementing regulations.

Spa industry is locally bound to the natural medicinal resources (water, peloids, gases and climatic conditions) so it has a purely regional nature. Therefore, its significance is not the same in all regions of the Czech Republic (Attl \& Studnička, 2012). Most of the spa industry is concentrated in Karlovy Vary Region (129 668 visitors), as well as in South Bohemia Region (48 028 visitors), Zlín Region (36 525 visitors) and 
Olomouc Region (27 671 visitors). On the contrary, Vysočina Region and the Prague Region are entirely without spa industry (ÚZIS, C2015).

After a decline from the previous years, also the Czech spas are starting to fill up again, interest of tourists in spas from the beginning of 2015 dramatically increased. Many spas are now investing, but these investments are not yet as immense as they could be. In addition to spa owners, also the biggest Czech insurance company (VZP) confirms the increase in the number of clients who visited Czech spas. In January 2013 VZP registered spa stays with 2108 clients, in the same period in 2014 with 2412 clients, and in 2015 it was about 3622 clients. With the growing number of patients also the expenditures per insured are increasing as well as stays at spas. In 2013 it was 821 million clients, in 2014 it was 1.293 billion clients, and in 2015 the number of patients increased by an additional one hundred million. From the above figures it is certain that the number of patients who can afford spa treatments in spa facilities abruptly increased by fifty percent - and it is because of the abolition of restrictive decree of the Ministry of Health (Czech Television, (C) 1996-2016).

However, the new millennium has brought concerns about the future of the spa facilities in its classical form as a part of a comprehensive health care system. As a right step to enhance the sustainability and competitiveness of Czech spas appears to be the creation of interconnection of classic spa treatments and procedures with cultural or sports activities, so that spas can appeal to new market segments, especially young families with children, because this group contributes significantly to the domestic tourism, and currently it is the most promising segment of tourism (Orieška, 2010). Part of the revenue of the spa facilities is from health insurance companies for patients who have received a complex medical care. The health care system is characterized by the following tendencies as shown by Popesko and Tučková (2012) in the system is a tendency to increase the proportion of expenditure on health care and average spending on health care is determined primarily by national income per capita, not the health needs of individuals. Increased per capita income is also a major factor explaining increased life expectancy. This also complements Tučková, Fialová \& Strouhal (2012): the Czech Republic ranks among countries with the lowest proportion of private expenditure. Not only for this reason should patients pay more into the system (e.g. additional insurance, above-standard care, higher patient's financial participation in treatment). There are considerable inadequacies regarding the patient care as well, i.e. quality.

\subsection{Tourism of families with children}

Young families profess lifestyle with a certain stability and quality of life and seek opportunities how to spend their free time away from their place of residence (Hesková, 2006). According to Indrová (2008), the most popular forms of tourism of families with children are rural tourism, visits to cities or cultural and sport events, recreational tourism, adventure tourism, day trips and group visits organized by institutions of tourism.

Tourism of families with children, however, calls for a special accommodation, food and leisure services, including special prices which will meet the needs and requirements of this market segment. The most common limiting factors that affect the participation of families with children in tourism are: the limited family budget, insufficient free time fund, children's age, attractions and activities offered by destinations, the suitability of the environment for families with children, cleanliness of the accommodation and catering facilities, security, peace and silence in the environment of vacation, level of simplicity of the travel, certainty of good weather, needs and attitudes of children, because parents are satisfied only if their children are satisfied. An important requirement of this segment is also often babysitting and appropriate 
animation programs that entertain children because parents want to leave aside a little time for themselves (Indrová, 2008).

For the market segment of families with children it is necessary to build hotels that will provide children with full facilities and will be prepared to meet special requirements and needs of parents and their children (Hörl, 2007). The main criterion should be a suitability of the hotel for children, childcare, facilities and offer of specialized services for children (Kostková, Němčanský, \& Torčíková, 2009).

Hotels that are oriented at child clients, families with children, mothers with children, but also at future mothers, are called family or children hotels (Linderová, 2008). The Official united classification of accommodation facilities in the Czech Republic nor Czech legislation does not know the category of accommodation facility "children hotel" or "family hotel". The term "children hotel" or "family hotel" is used in two senses: as a designation for the hotel specializing in the market segment of families with children, or as a designation for associations of family hotels, operated by Familotel, which is based in Upper Bavaria and owns 54 family hotels. Most of these hotels are located in holiday resorts in Germany and in the Alps. These hotels are subjected to strict rules regarding the scope and quality of services and facilities for families with children (Hörl, 2007).

It is predicted, that tourism of families with children will grow more than any other form of tourism, because family holiday represents a way how to unite all members of the family and it is also an opportunity for families to spend time together (Niemczkyk, 2015). This tendency was already noticed by the biggest Czech hotel chain, and subsequently the idea of baby friendly hotels was realized in recent years in the Czech Republic. It meant a new trend in the politics of family accommodation services in the country. Orea Hotels as the first came up with the brand "Baby Friendly" which ensures that the hotel can safely accommodate children. The company also launched a network of small hotels and guesthouses Family Inn which are accommodation facilities designed especially for families with children (Orea Hotels, 2011-2015).

\section{METHODOLOGY}

Due to the aim of this research, statistical methods used for processing data concern descriptive statistics and quantitative research. Firstly, it is necessary to capture time series by econometrics using absolute growth in order to find out the trend in visits in spa accommodation facilities in last few years. Simple econometrics is therefore used. Secondly, to support the main aim, the research must analyze in detail the current range of facilities for families with children on the Czech market. The analysis consists of three parts: an analysis of hotel services for families with children in the Zlín Region, analysis of hotel operators designed for families with children in other regions of the Czech Republic, and comparison of hotel services offer of these entities with the existing range of services for families with children in the selected spa facility. The analysis of existing facilities which are offering hotel services for families with children was based on criteria analysis as follows:

- accommodation facilities are classified as "Hotel" by the Official united classification of accommodation facilities in the Czech Republic;

- the hotel is located in the Czech Republic;

- the hotel was assigned as First Class (four stars) by the Official united classification of accommodation facilities in Czech Republic;

- the hotel is owner of Baby Friendly Certificate.

For the needs of this paper, quantitative research method was chosen to collect measurable numerical data of the studied issue (Gúcik et al., 2011). Based on Nykiel (2007), testing of the whole population is too general and financially demanding, therefore we have aimed at testing the representative sample in the target 
group segment. Target group was chosen as a segment of families with children. Quantitative research was then used for identifying the needs and demands of this segment in terms of equipment and services provided in spa facilities. Both primary and secondary data were used to support the results of this research. Primary data were conducted in the form of questionnaire survey whereas secondary data were retrieved from the Czech Statistical Office as the main and complex source of tourism statistical information for the Czech Republic.

The research question that was asked at the beginning of this research is what are the trends and services that families with children would prefer during their stay in spa facilities. Based on the results from this research question, further research can be implemented by accommodation facilities and their marketing strategy. To determine the preferences, needs and requirements of the target group, primary data were obtained through quantitative research method. For the selection of the target group, these segmentation criteria have been identified:

- geographic criterion: families living in the Czech Republic;

- demographic criterion: families in the phase of full nest I and full nest II (Palatková, 2006; Ryglová, Burian, \& Vajčnerová, 2011).

The questionnaires were distributed to families with children during their stays in the children's hospital which is owned by the selected spa facility. Questionnaires were also filled out by the visitors of the spa area. The questioning was conducted in the period from 2 February to 1 April 2015. During these months, 197 questionnaires were filled out which is considered to be representative sample for the aims of this research.

\section{KEY RESULTS}

Based on the conducted analysis of the hotel services offer for families with children on the Czech market, we can now state that only 3 First Class hotels certified by Baby Friendly Certificate are currently located in the Zlín Region. In other regions of the Czech Republic there are 10 First Class baby friendly hotels. The best range of services for families in the price/quality ratio has Hotel Vitality (Moravia-Silesia Region) and Aquapalace Hotel Prague (Prague Region). As the analysis showed, hotel services offers of other hotels are comparable - they all meet the basic requirements of Baby Friendly Certificate.

According to the demographic research of the Czech Statistical Office, in 2011 there were 2805949 households in the Czech Republic, of which 1297529 (43.5\%) were families with children. The number of families according to the number of children in the family were following (graph 1).

The demographic trend is currently directed towards reducing the number of children in families. This is interpreted also from the secondary statistical results in the graph. In 2011 the average number of children per household in the Czech Republic was 0.67 (ČSÚ, C2014).

According to UNWTO and ETC (2010) the birth rate in 2030 in Europe will be stabilized at 1.7 children per woman, of course with regional differences. This value will be affected by many factors. The most important one will be particularly significant reduction in infant mortality, increasing proportion of working women or declining importance of the need to have a male child. Another significant trend is the transition from vertical family, where many members of the family were from one generation, to the horizontal family, where family is more interwoven across generations. This is a manifestation of an aging population combined with fewer children in the family. Currently, there is also a trend of family reunion during the holidays - two parts of families come together to one place that will be holiday for all (CzechTourism, 2011). 


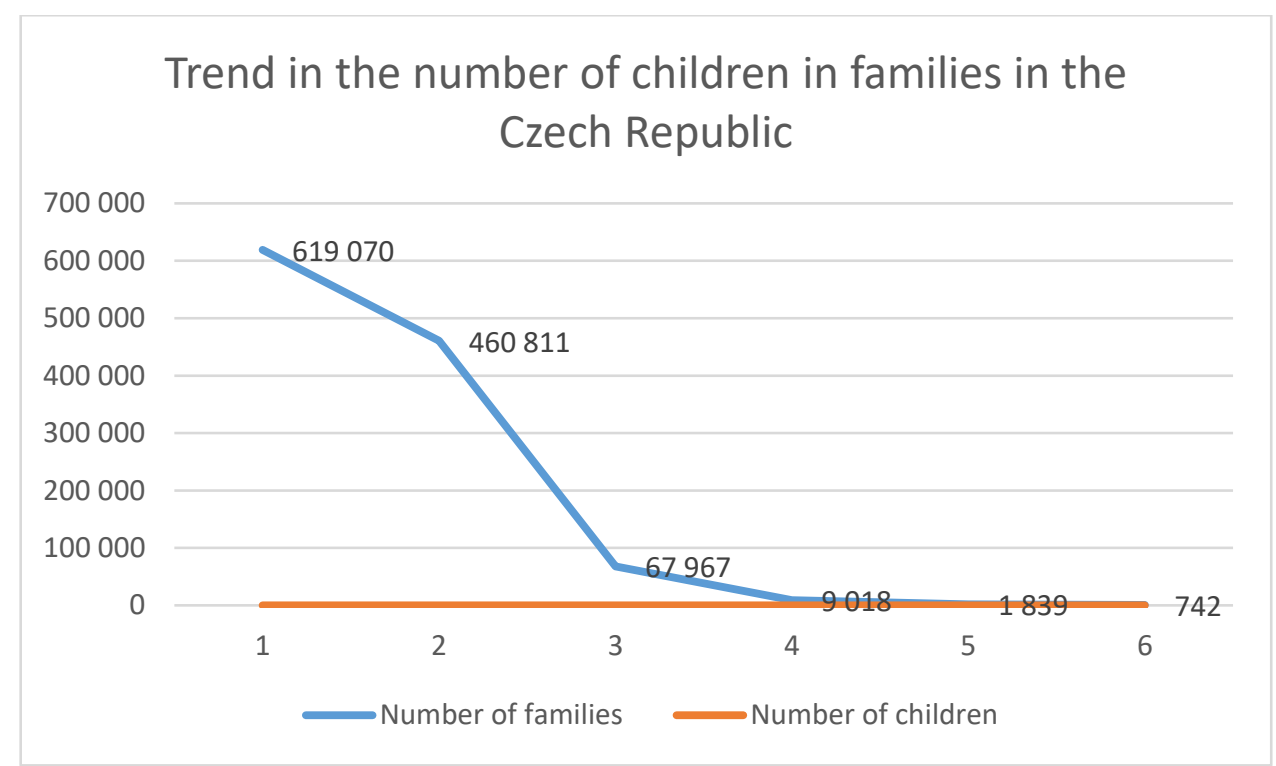

Graph 1. Trend in the number of children in families in the Czech Republic Source: own processing based on Czech Statistical Office

From the conducted research of the market segment of families with children arose following conclusions:

- a typical is summer vacation in the Czech Republic, which families organize themselves;

- for families with preschool children a traveling is difficult, therefore, they prefer making short trips;

- traveling with children of school age is much less demanding, these families prefer long distances and seek for an active vacation (hiking, cycling, visiting castles and cultural events or spending time on the water);

- ideal accommodation facility is cottage or hotel;

- optimal length of a family holiday is two weeks;

- the most attractive regions are Šumava, South Bohemia and South Moravia;

- for families are crucial information about local attractions, prices of services, quality of accommodation and information about local hiking and biking trails, a great role also plays safety, the environment and climatic conditions when choosing a holiday (CzechTourism, 2005-2013).

When analyzing spa facilities in the Czech Republic, appropriate attention should be paid also to the visitors' arrivals to the Czech spa accommodation facilities which is displayed in Table 1.

Table 1

Average absolute range of growth of number of guests in Czech spa accommodation facilities (2012-2016)

\begin{tabular}{|l|c|c|c|c|c|}
\hline & 2013 & 2014 & 2015 & 2016 & Average absolute growth \\
\hline Number of guests & 35077 & -3654 & -10005 & 47846 & 13853 \\
\hline Non-residents & 25213 & -24256 & -32353 & 23286 & -1622 \\
\hline Residents & 9864 & 20602 & 22348 & 24560 & 15475 \\
\hline
\end{tabular}

Source: own processing based on Czech statistical office (2012-2016) 
Figure 2 provides information on the perception of respondents about the services and amenities that should hotel for families offer. Most respondents would appreciate animation programs for children $(28 \%)$, babysitting services (17\%), equipped children's playground (17\%) and children's park (17\%). Furthermore, families mentioned special children's menu, rent or sale of children's equipment and sport equipment for children (children's bikes, toy cars, tricycles, scooters, skipping ropes, balls).

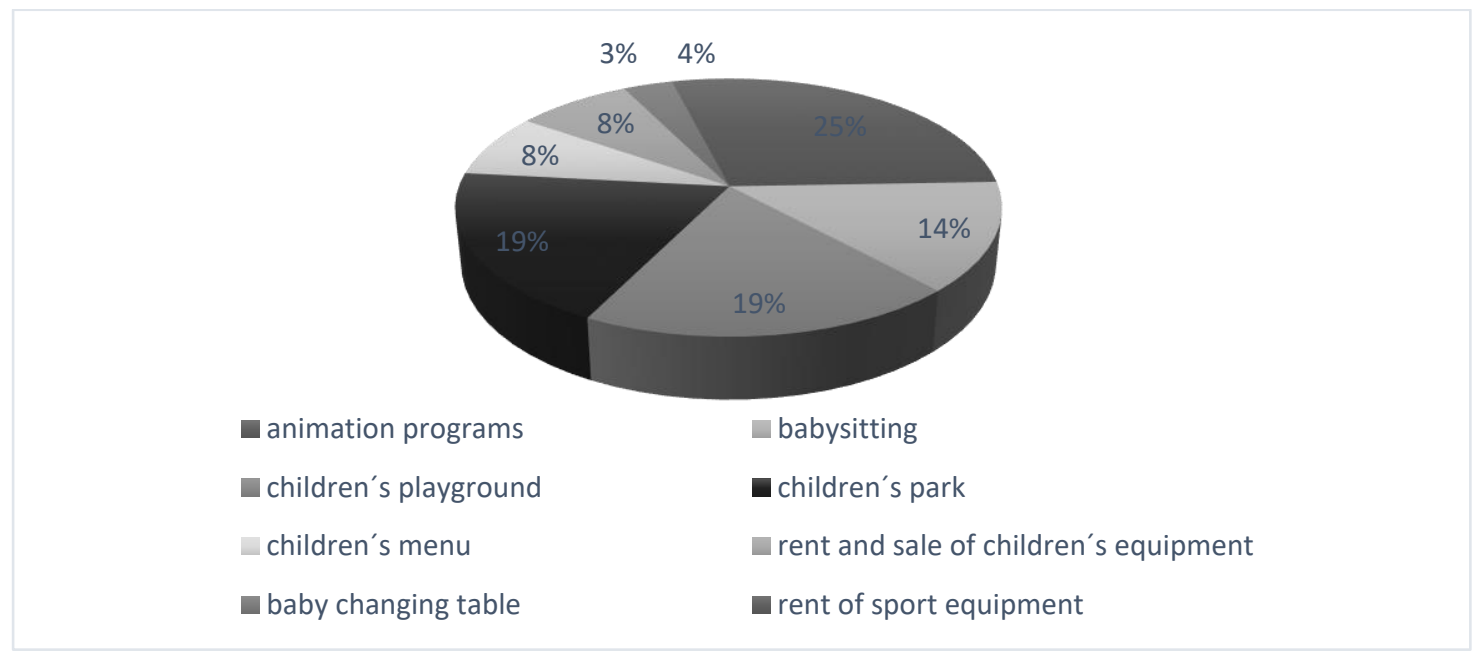

Figure 2. Family friendly hotel services and amenities

Source: author's own processing

Further was found out what amount of money are families with children willing to pay per person for 1 night stay in hotel. The largest proportion of respondents would pay 1 001-1 $500 \mathrm{CZK}$ (53\%), 30\% of respondents would spend $1501-2000 \mathrm{CZK}$, and 15\% of respondents chose option $1000 \mathrm{CZK}$. According to the Czech Statistical Office survey (2015) households spend on their holiday an average of 2782 CZK per person and year, which represents $9.5 \%$ of total consumer expenditures of Czech households. According to other surveys, it seems certain that the target group is willing to spend more money on vacation. In addition, it is also true that families with children did not give up on their vacation even at the time, which was referred to as a crisis (ČSOB, 2013). These data show moderate optimism in the sphere of tourism development, and the expected recovery of this segment (pdMEDIA Ltd., C2003-2015).

Another question in the conducted quantitative research related to the length of stay at hotel. The largest proportion of respondents would vote for the length of 4 days or longer (56\%), 33\% of respondents would prefer the length of 3 days, and the remaining 11\% preferred 2 days. Respondents were also asked an open question, which concerned the ideal composition of accommodation package. The largest share was accommodation services (15\%), food by half board (12\%), full-day programs for children ( $9 \%$ ), and babysitting (9\%). Another preferred service was unlimited access to the spa (9\%), horse riding $(6 \%)$, renting bicycles $(6 \%)$, organized trips $(6 \%)$ or tickets to the zoo $(6 \%)$. Families with children would during their stay prioritize Czech cuisine (28\%), healthy food (27\%), or regional cuisine (26\%). The smallest interest was expressed in foreign cuisine $(12 \%)$ and a vegetarian food $(7 \%)$. The last question was about the way the respondents obtain information about accommodation. The most common way to find information about accommodation facilities is the internet (44\%), then recommendations of friends or family $(35 \%)$, and the rest of the respondents receive information from print media $(12 \%)$, radio and TV $(6 \%)$ or from the information centres $(3 \%)$. 


\section{CONCLUSION}

As mentioned by Tabacchi (2010, p.103), typical purpose of spa until 1970s was wellness "managed by physicians and built around hot mineral springs". However, after few years, the perception of spas has changed significantly in the eyes of tourists followed by a substantial growth within last twenty years. (Tabacchi, 2010) Nowadays, spa tourism attracts tourists not only for medical but also relaxation purposes. The unambiguous conclusion of the research is that the market segment of families with children constitutes a highly promising group of customers, and this applies not only for the selected spa facility in the Czech Republic. Therefore, it is necessary to adapt the facilities of hotels, hotel services and leisure activities for this target group.

Even with respect to the identified lack of hotel services for families with children (private patient stays) in selected spa facility, it would be appropriate to create new services portfolio which would be focused on the target group. Particular attention should be paid mainly while ensuring required personnel conditions to provide all hotel services. Quality staff will be decisive element of success of the new service portfolio, as the hotel staff will be in direct contact with the guests, so their activities can significantly affect how clients will be satisfied during their stay. Among others, also a special importance should be given when ensuring complete institutional, material, financial and organizational conditions.

Based on the results mentioned in the previous section, it would be suitable to propose a specific portfolio of hotel services for specific market segment - Czech families, specifically for families in the phase called full nest I (families with children under 5 years) and full nest II (families with children from 6-12 years), mainly from the mid-income to high-income groups. This goal will be achieved through a comprehensive marketing mix of the product. By introducing a new portfolio of services, year-round offer of services and stays of spa facilities will be extended, also the competitiveness at the tourist market of families with children will increase, and ultimately a new market segment will be reached. From the perspective of potential customers, the new service portfolio will mean the opportunity to spend a family holiday in quiet surroundings of Czech spa, and in a hotel that will offer quality services which will meet the needs and demands of their children.

In our opinion, this product has a tendency to be viable for a long time, because children decide on the next visit of the hotel; also children are simultaneously future client for a hotel. Based on the data obtained from the analyses, we can conclude that demand for this product will grow, as mentioned above, families are interested in baby friendly hotels in the Czech Republic, services such as babysitting or organizing animation programs for children are nowadays necessary. Due to the diverse market and new challenges, it is necessary also for other Czech spas to focus on this new target group that could appropriately complement and expand their portfolio of services. Specialized programs which should attract especially families with children are upcoming trend of modern spa industry. In the next seasons, Czech spas should try to present itself as the place of strong emotions - cultural, sporting and gastronomic. The main focus of spa facilities should be paid to adjust their own activities so that they will be able to offer a pleasant holiday experience to young families. Spas should also focus on the creation of appropriate programs for children.

The limitations of this research are seen in more deep research that could provide information about the potential for sustainable growth of spa facilities in the Czech Republic for this target group. This is also the aim of the future study that will be aimed at selection of sustainability criteria and indicators that will provide hotel spa facilities with better economic growth. 


\section{ACKNOWLEDGEMENT}

The author is thankful to the Internal Grant Agency of FaME TBU No. IGA/FaME/2017/017 (Economic sustainability in spa facilities) for financial support to carry out this research.

\section{REFERENCES}

Attl, P. (2011). Výžnam lázeñ̌ského cestovního ruchu pro regionální rožvoj. Jihlava: Vysoká škola polytechnická Jihlava.

Attl, P., \& Studnička, P. (2012). Financováni českébo lázenňství z prostrédkì Regionálních operačnich programù Hradec, Králové: Gaudeamus.

Česká televize. (1996-2016). Lázně zahajují sezonu, zájem o ně skokově vzrostl. Ceska televize.cz[online]. Rretrieved from http://www.ceskatelevize.cz/ct24/domaci/1527122-lazne-zahajuji-sezonu-zajem-o-ne-skokove-vzrostl

Chen, Chih-HungInformach; Wu, Ming-Hsuan; Huang, Yu-An; Cheng, Jen-Son. (2013), International Proceedings of Economics Development and Research; Singapore 67: 25-29. Singapore: IACSIT Press.

Cohen, M., \& Bodeker, G. (2008). Understanding the Global Spa Industry: Spa Management. Oxford: Elsevier.

ČSOB. (2013). Výběr z pruizkumu Index očékávání firem: Analýza stavu a očekávánív cestovnim ruchu. Praha: Datank, s.r.o.

Crech statistical office. (2012-2016). [online]. [cit. 2017-02-15]. Available at z: https://www.czso.cz/

ČSÚ. (2014). Demografická príruckea 2013. Czso.cz[online]. [retrieved 2017-03-29]. Available from: https://www.czso.cz/csu/czso/demograficka-prirucka-2013-hjxznso9ab

ČSÚ. (2015). Vydáni a spotréba domácností: Statistiky rodinných úctuo. Praha: Czech Statistical Office. ISBN 978-80-250-26298.

Czechtourism. (2005 - 2013). Domácí cestovní ruch v Céské republice. Czechtourism.cz[online]. [retrieved 2017-03-26]. Available from: http://www.czechtourism.cz/files/statistiky/motivaceregiony.pdf

Czechtourism. (2005 - 2013). IOP - Sběr dat - DCR - ČR. Czechtourism.cz[online]. [retrieved 2017-03-26]. Available from: $\quad$ http://www.czechtourism.cz/marketingoveaktivity/evropske-projekty/iop-sber-informaci$\% \mathrm{E} 2 \% 80 \% 93-\mathrm{dcr}-\% \mathrm{E} 2 \% 80 \% 93$-cr/

Czechtourism. (2005 - 2013). Motivace ke návštèvé Céské republiky. Czechtourism.cz[online]. [retrieved 2017-03-26]. Available from: $\underline{\text { http://vyzkumy.czechtourism.cz/analyzy/0101 .pdf. }}$

Czechtourism. (2005 - 2013). Výžkum zamèrený na domáci cestovní ruch. Czechtourism.cz[online]. [retrieved 2017-03-26]. Available from: http://www.czechtourism.cz/getmedia/25fdb6e6-742a-471a958ed874511a0c6a/12 0115 zaverecna zprava 2010 2014.pdf.aspx

Czechtourism. (2011). Demografické żmèny a cestovní ruch. Czechtourism.cz[online]. [retrieved 2017-03-29]. Available from: http:/ vyzkumy.czechtourism.cz/\#;q=demografick $\% \mathrm{C} 3 \% \mathrm{~A} 9 \% 20$ trendy;orderby=novinky

Erdelia, G. et al. (2011). Romanian Spa tourism: A Communist Paradigm In a Post Communist Era. Human Geographies - Journal of Studies and Research in Human Geography, 5(2), 41-56.

Georgiev, G., \& Vasileva, T. (2010). Conceptualization and classification of balneo, SPA and Wellness establishments in Bulgaria. UTMS Journal of Economics, 1(2), 37-44.

Gúćik, Marian a kolektív. (2011). Marketing cestovnébo rucbu. Banská Bystrica: Univerzita Mateja Bela, Ekonomická fakulta. ISBN 978-80-89090-85-3.

Hall, C.M. (2013). Medical Tourism: The Ethics, Regulation, and Marketing of Health Mobility. London: Routledge, ISBN: 9780-415-66575-9.

Herget, J., Petrů, Z., Abrhám, J. (2015). City branding and its economic impacts on tourism. Economics and Sociology, 8(1), 119-126. DOI: 10.14254/2071-789X.2015/8-1/9.

Hesková, M. (2006). Cestovní rucb: pro vyšš̌ odborné školy a vysoké skooly. Praha: Fortuna. ISBN 80-7168-948-3.

Hörl, G. (2007). Definition Familotel - Kinderbotel - Familienhotel. In: Familienhotel [online]. June 15, 2007 [retrieved 201603-23]. Available from: http://familienhotel.blogspot.cz

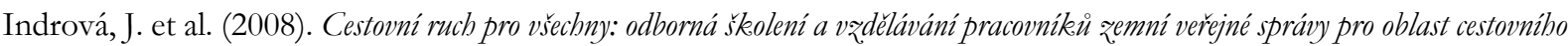
ruchu. Praha: MMR ČR. ISBN 978-80-7399-407-05.

ING. (2014). Dovolená Céchũ v roce 2014. Praha: PR agentura - Stance Communications. 
Jelínková, D. (2015). Projekt portfolia služeb pro trěnni segment rodiny s dětmi v Lázně Luhačovice, a.s. Zlín. Diplomová práce. Univerzita Tomáše Bati ve Zlíně, Fakulta managementu a ekonomiky, Ústav podnikové ekonomiky. Vedoucí diplomové práce Zuzana Tučková.

Kostková, M., Němčanský M., \& Torčíková, E. (2009). Management slǔ̌eb cestovního ruchu. Karviná: Slezská univerzita v Opavě, Obchodně podnikatelská fakulta v Karviné. ISBN 978-80-7248-510-9.

Linderová, I. (2008). Ekonomická revue cestovnébo ruchu. Banská Bystrica: Ekonomická fakulta UMB Banská Bystrica. ISSN 0139-8660.

Molnár, C. (2010). Health Tourism in Hungary: History, its Revaluation and Tendencies. Journal of Tourism Challenges \& Trends, 3(2), 101-114.

Moraru, R. C., \& Molnar, E. I. (2015). Relations, Assessment Methods Travel Industry. Knowledge Horizons. Economics, 7(4), 51-54.

Nejdl, K. (2005). Lázeňství v České Republice na křižovatce svého vývoje. Cz̨ech Hospitality and Tourism Papers, 1(2), 818.

Niemczyk, A. (2015). Family Decisions on the Tourist Market. Economics and Sociology, 8(3), 272-283. DOI: 10.14254/2071-789X.2015/8-3/19.

Nykiel Ronald, A. (2007). Handbook of Marketing Research Methodologies for Hospitality and Tourism. New York: The Haworth Hospitality and Tourism Press. ISBN: 978-0-7890-3426-7.

Orea Hotels. (2011-2015). Napsali o nás. Orea.cz [online]. [retrieved 2016-03-24]. Available from: http://www.orea.cz/cz/18.hotel-kde-se-deti-neboji

Orieška, J. (2010). Slǔ̌by v cestovním ruchu. Praha: Idea servis. ISBN 978-80-85970-68-5.

Palatková, M. (2006). Marketingová strategie destinace cestovního ruchu: jak získat více přjmů z. cestovníbo ruchu. Praha: Grada. ISBN 80-247-1014-5.

pdMEDIA s.r.o. (2003 - 2016). Cestovní ruch očekává oživení. Zlatakoruna.cz[online]. [retrieved 2015-03-29]. Available from: http://www.zlatakoruna.info/zpravy/nezivotni-pojisteni/cestovni-ruch-ocekava-oziveni

Ryglová, K., M. Burian \& I. Vajčnerová. (2011). Cestovni ruch-podnikatelské principy a prǒležitosti v praxi. Praha, Grada. ISBN 978-90-247-4039-3.

Stanciulescu, G. C., Diaconescu, G. N., \& Diaconescu, D. M. (2015). Health, SPA, Wellness tourism. What is the difference? Knowledge Horizons. Economics, 7(3), 158-161.

Tabacchi, Mary. H. (2010), Current Research and Events in the Spa Industry. Cornell Hospitality Quarterly. 51, (1), 102-117. DOI: https://doi.org/10.1177/1938965509356684

Tučková, Z., Fialová, Š., \& Strouhal, J. (2012). Health care systems: Some comparative analysis from Czech perspective. International Journal of Mathematical Models and Methods in Applied Science, 6(2), 297-304. ISSN 1998-0140

Tučková, Z., \& Popesko, B. (2012). Utilization of process oriented costing systems in healthcare organizations. International Journal of Mathematical Models and Methods in Applied Science, 6(1), 200-208. ISSN 1998-0140.

UNWTO et. ETC. (2010). Demographic Change and Tourism. Madrid.

Úzis Čr. (2012). Lázeñská péce 2011: Zdravotnická statistika. Praha: ÚZIS ČR.

Úzis Čr. (2015). Lázeňská péce 2014: Zdravotnická statistika. Praha: ÚZIS ČR.

Vystoupil, J., Šauer, M., \& Studnička, P. (2011). Analýza podpory rozvoje cestovního ruchu v České republice z Regionálních operačních programů v období ŕíjen 2007 - červen 2010. Cžech Hospitality and Tourism Papers, 7(12), 24-48.

Zákon č. 164/2001 Sb., o prírodních léčivých zdrojích, zdrojích přírodních minerálních vod, prírodních léčebných lázních a lázeňských místech a o změně některých souvisejících zákonů (lázeňský zákon). 